\title{
A risk management approach for collaborative NPD project
}

\author{
Ioana Filipas Deniaud \\ Strasbourg University \\ BETA \\ Strasbourg, France \\ deniaud@unistra.fr
}

\author{
François Marmier \\ Toulouse Univ., Mines Albi \\ \& Strasbourg Univ., BETA \\ France \\ marmier@mines-albi.fr
}

\author{
Didier Gourc \\ Toulouse University \\ Mines Albi \\ Albi, France \\ gourc@mines-albi.fr
}

\author{
Sophie Bougaret \\ Pharmaceutical R\&D \\ Management Consulting \\ Company - Manageos, \\ Francarville, France \\ sophie.bougaret@wanadoo.fr
}

\begin{abstract}
To be competitive, a new product should present an innovative advantage while being achievable. To ensure the success of a New Product Development (NPD) project, specific skills and resources are required. Most often, if a product is complex, a unique company doesn't have all the competences to provide the complete product. In this case alliances must be formed to create a collaborative network that work on the new project. Depending on the selected partners, different possible innovation level can be reached. This decision also influences the uncertainty and the risk of the project. It is difficult to assess the risk level of a NPD project especially when the collaborative network is new. In this paper we address the topic of alliance making in NPD and we present a reading frame of the projects by taking into account the type of innovative projects, the possible network and the risk that are obviously inherent. The originality of the paper is to consider correlate decisions focused on the collaborative network and on the risk management in innovation context. The objective of the paper is to establish the process making the ling between network design, NPD project planning and risk management in order to have an overview of the repercussion of the network design on NPD project.
\end{abstract}

Keywords-new product development; project management; collaborative network; risk management; innovation.

\section{INTRODUCTION}

Future success of a company often requires that firms offer regularly new products. In order to reach fundamentally better products, lower costs, and basically new product features, technological innovations are needed [1]. Higher requirements for the products lead to the need for constant innovation for company's competitive advantage. In the same time the complexity of technology needed to innovate has increased and NPD costs are exploding [2]. Firms with diversified networks usually hold major advantages through access to a rich knowledge base. Ritala and al [3] show that the external knowledge sharing increased firm-level innovation performance. External knowledge sharing appeared in collaborative network and forms an open innovation system [4] with advantage and difficulties.

Nightingale [5] point out that NPD simultaneously implies defining the product to be created (What do we do?), defining the project to implement (How do we do it?) and the actors in charge of different activities (Who does what?). The NPD project contains a set of activities that must be carried out to meet design objectives. The innovation level of the future product involves a creative capital [6]. The NPD is the result of a collaborative process between resources belonging to different functions of the same company (internal development) or between different companies working networked [7]. Both innovation level and collaborative network are sources of risks.

To identify the risks and propose a risk management plan, the objective of this work is to propose a reading frame for collaborative NPD project. The originality of this work is to consider the type of project, the type of collaboration and the type of risk in order to help choosing the risk treatment strategies.

The paper is structured as follow: first, we present of short literature review on NPD Project and its characteristics, second we propose a process and a reading grid helping to define a risk management plan and then finally, we present our conclusions

\section{NEW PRODUCT DEVELOPMENT PROJECT}

A NPD project is characterized by an innovation level, most often the time by distributed skilled resources between partners and by a high level of risk. Therefore, in this section, we define these particular notions.

\section{A. The innovation and its effect on the project}

NPD collaborative project has four main steps: Requirements specification (including idea genesis), Product design, Product implementation, and Commercialization. This steps are formalized as a sequential process (stage-gate process), or a concurrent, iterative one (Vee cycle) [8]. Several authors distinguish three NPD project types according to the initial innovation level. In the Gero's classification [9] defined the design output can be creative, innovative or routine. In the Evbuomwan et al.'s [10] classification the level of originality is obtained by routine design, to redesign and non-routine design. In reality, it is often not possible to define precisely the boundaries between theses types of design. For example, a 
complex product is composed by different sub-systems [11]. One of sub-systems maybe corresponds to innovative design, while another is routine design. Therefore, this should be considered to be only a broad classification. In reality it is a continuum.

$\mathrm{Du}$ to the innovation, NPD project are risky. Innovation demands coordination and cooperation between partners in NPD. The types of collaborations are described in the next section.

\section{B. Collaborative network and partners election}

To realize a collaborative work a form of cooperative arrangement, named "strategic alliance", must to be done between partners [12].

\section{1) Definition}

NPD project may imply a "co-development alliance "[13] or "Technology development alliances" [14], with the purpose of improvement in technology and know-how, for example agreements for joint $\mathrm{R} \& \mathrm{D}$, simultaneous engineering, licensing, joint design and/or technology commercialization. It can be done in particular bi-lateral relations or in clusters and during each step of the project, alliances can by done. Those involve the sustained joint creation of property and knowledge for the partners, requiring them to bring in resource and work together on a constant basis [15]. Depending on project time (moment) the company that initiates the collaborative process may seeks partners with a strong creative potential (in initial phases) towards simple subcontractors (at the end of the project).

Many theoretical frameworks dealing with strategic alliances with very different perspective of innovations; in neo-classical theories, technology or innovations are simply assumed to appear, from time to time, resulting from economically exogenous processes. Schumpeter [16], contrary to the standard neo-classical theory, point out the endogenous character of technology and innovation (mainly in-house R\&D). Gnyawali and Srivastava [17] discus about network orientation and they identified two possibilities: acquisition and co-development. In acquisition, network is viewed as means to get specific resources of the other firm to enable to pursue its own innovation in NPD. In co-development orientation network is viewed as a way of pursuing innovation together with its partners in joint NPD. Several typology of collaboration was proposed in literature $[15 ; 18 ; 19]$. Figure 1 we present our synthesis of those typologies.

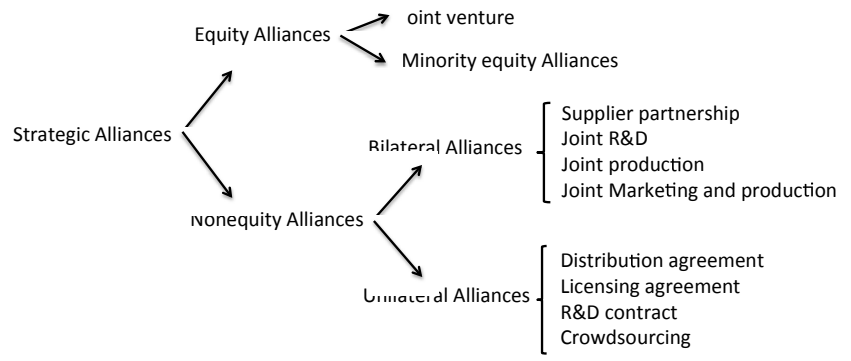

Fig. 1. Alliances typology

\section{2) Innovation in network}

Firms pursuing innovation must maintain a balance between learning from external (exploration) and internal sources (exploitation). Too much exploitation is unlikely to lead to higher-order learning, whereas too much exploration is expensive and may produce many underdeveloped concepts and ideas [20]. This supposes the capability to make alliances with other firms with it's risk-taking propensity to devote resources to projects. Since 1960 , in the R\&D alliances, firm increasingly prefer contractual partnership to joint venture [21]. To encourage innovation in NPD, two types of nonequity alliances (figure 1): unilateral alliance (R\&D contract...), bilateral alliance (joint R\&D...).

- In unilateral alliance one partner provides founds to another partner for specified R\&D development. In this case there are no knowledge sharing between partners and innovation level tends to be low;

- In bilateral alliance, partners combine their knowledge. "Novelty gain" increases with cognitive distance between partners [22]. Innovation level is directly proportional with novelty gain

3) Strategy of alliance selection

Emden et al [13] identified three conditions for the creation of value in co-development network:

- Strategic alignment focuses on selecting partners with maximum potential to collaborate. This implies motivation correspondence and goal correspondence between all network partners.

- Technological alignment focuses on selecting partners with maximum potential for creating technological synergy. Partners must have either an innovative technology or expertise in certain domain.

- Relational alignment focuses on selecting partners with maximum potential to sustain the relation-ship.

In NPD, few firm's specific resources may lead to firm's competitive advantage [23]. However, 'the 'do it yourself' mentality in technology and R\&D management is outdated" [24]. A network is realized by pooling the various resources/ competences of the partners. Das and Bing-Sheng Teng [12] propose an integrated resource based view of strategic alliances, identifying four types of resources that the partners bring to an alliance: Financial, Technological, Physical and Managerial.

\section{Risk management in Network}

Firms trying to be innovative develop new ways of doing business. R\&D activities usually connote higher risks for firms. However, depending on the partners and on the different resources shared in an alliance (financial, technological, physical, managerial) different risks are possible. Two types of risks in alliances have been identified in the literature: relational risk end performance risk [26; 12 ; 15]:

- Relational risks are those regarding cooperation (eg. partners opportunistic behaviour). 
- Performance risks are those regarding future states of the alliance objectives (eg. objectives are not achieved).

In NPD alliances, both relational risk end performance risk tend to be high [25]. The two sets of risks present an inverse evolution of level with the increase of the number of partners. The performance risk is usually shared by making alliances but the relational risk appears only if an alliance is made [27]. The greater the number of previous alliances between the same partners, the lower will be the perceived relational risk. The collaborative experience also has an influence on the risk level. The greater the asymmetries between partners, the higher will be the perceived relational risk [15].

The technology knowledge helps solving technical problems. This point is a key factor of the risk level in NPD project. However, other factors exist. Tornatzky and Fleischer [28] framework highlights the three main elements of a firm's context influencing the process by which it adopts and implements technological innovation: Organization, Technology, and External Task Environment. In the same ideas Wohlfeil and Terzidis [1] identified different critical success factors in technological innovation splited in three categories: Target market, organization and Technology. All this factors generate risks.

Other kind of risks, exogenous of network, are possible. They are mentioned below but are not considered in this work. These external risks depend on target market:

- Market barriers: high capital demand, patent situation, image requirements, lack of appropriate location, resources or suppliers, economy of scale.

- Environmental context: technology support infrastructure, social, political (government regulation), economic, legal, etc.

\section{Finding}

Depending on the innovation level of the project and on the collaboration involved in the development, different risks are possible. The strategies needed to manage risk and to success the project different on the type of the considered risks.

Consequently, to make the project robust to the possible risk, strategies of risk management have to be anticipated. To identify risks and propose adapted risk treatment strategies, is necessary to be able to characterize a project following the three dimensions presented in the literature review (Innovation level, collaborative network and type of risks).

\section{A DECISION SUPPORT APPROACH}

To help in designing risk management plan, we take into account innovation and risks aspects in collaborative NPD project. First we formalized the process to build the risk management plan. This process uses the characteristics of the project to achieve efficient plan. Second, to categorized projects, we propose a structured frame of these characteristics. Third, based on the identified project category, we propose a table making the correspondence with their possible risks and associated treatment strategies to define risk management plan.

\section{A. Risk management in collaborative project design}

During the NPD project is designed, risks are studied. Figure 2 presents the macro process leading to the risk management plan design. This one starts from the specifications. The first constituting process consists in defining the deliverable and a macro vision of the project planning. The level of innovation drives the manager to develop incrementally the new product based on existing products or a radically different one. Since the knowledge capitalisation helps to be efficient, incremental innovation can be quickest than radical ones. It has a huge influence on the result of this process.

The second process consists in selecting the different partners, if needed, to achieve the project. In innovative product development presenting research the three main types of collaboration are the crowdsourcing, the joint R\&D and the R\&D contract to develop products. Mainly due to the skills of the selected partners the product design can change. The planning of the project and the associated project can have to be reviewed.

The third process aimed to develop a risk management plan. After having identified the different risks, strategies of treatment are proposed for each one of them. These strategies induce modification of the planning to prevent risks and or correct the effect of possible occurrences. [29] proposes a project management approach based on a synchronized process of project schedule and risk management. This synchronized process has been used for decision-making support in variant of project selection [30] and for product selection in [31]. These works do not considered the effect of the alliance selection on the planning and on the risk.

Therefore, risk treatment strategies generally conduct to review the product design or the project planning as well as to modify the collaborative network.

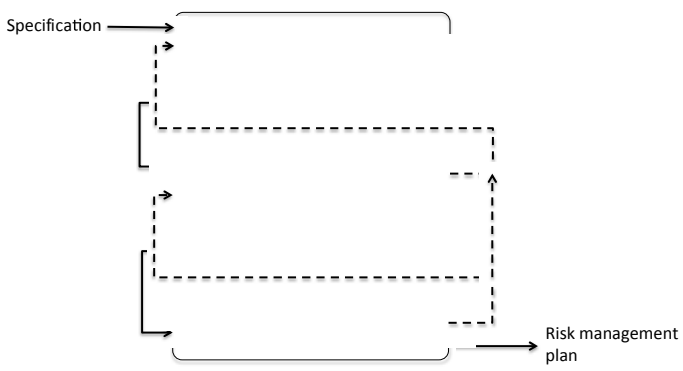

Fig. 2. The macro process of risk management plan design

This macro-process conducts then to position the project or a phase of the project in the structure proposed in the next section.

\section{B. A structuring frame}

Three characteristics are therefore considered here. The innovation level with the incremental or radical innovation. The network, with the Crowdsourcing, the Joint R\&D project. 
The type of risk with the relational and the performance risk. The cube obtained presented in figure 3 show in each cells the intersection of this decomposition. Each cell represent contexts where the project will be carried on and for which risk treatment strategies have to be proposed.

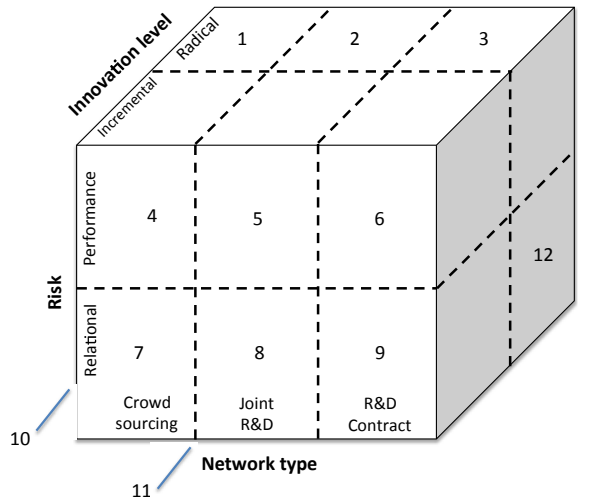

Fig. 3. The macro process of risk management plan design

\section{Risk management}

For each cell of the cube the literature identify different risks and possible treatment strategies. The table 1 presents for each cell of the cube examples of risks and associated treatment strategies. These sets are provided in order to drive the decision maker in the identification of the risks and in the risk treatment strategies to provide a risk management plan.

TABLE I. Risk example and strategies for each cell of the cube

\begin{tabular}{|c|c|c|c|c|c|}
\hline \multirow[t]{2}{*}{$\begin{array}{c}\mathrm{Ce} \\
\text { ll }\end{array}$} & \multicolumn{3}{|c|}{$\begin{array}{c}\text { Characteristics of } \\
\text { the project }\end{array}$} & \multirow[t]{2}{*}{ Risks } & \multirow[t]{2}{*}{ Strategies } \\
\hline & Innov. & Net. & Risk & & \\
\hline 1 & $\begin{array}{l}\text { Radica } \\
1\end{array}$ & $\begin{array}{l}\text { Cro } \\
\text { wd } \\
\text { S. }\end{array}$ & $\begin{array}{l}\text { Perf } \\
\text { o. }\end{array}$ & Non lead users integration & $\begin{array}{l}\text { Users integration } \\
\text { Intellectual propriety } \\
\text { rights sharing } \\
\text { (Hagedoorn, 2003) } \\
\text { Patenting }\end{array}$ \\
\hline 2 & $\begin{array}{l}\text { Radica } \\
1\end{array}$ & $\begin{array}{l}\text { Joint } \\
\text { R\& } \\
\text { D }\end{array}$ & $\begin{array}{l}\text { Perf } \\
\text { o. }\end{array}$ & $\begin{array}{l}\text { Low resources flexibility } \\
\text { Difficulty to adopt } \\
\text { technology by partners } \\
\text { (Feasibility \& Maturity) }\end{array}$ & Joint-Patenting \\
\hline 3 & $\begin{array}{l}\text { Radica } \\
1\end{array}$ & $\begin{array}{l}\mathrm{R} \& \\
\mathrm{D} \\
\text { Cont } \\
\end{array}$ & $\begin{array}{l}\text { Perf } \\
\text { o. }\end{array}$ & $\begin{array}{l}\text { Financial shortfall } \\
\text { Non profit } \\
\text { No appropriate Time-to- } \\
\text { market } \\
\text { No appropriate Time-to- } \\
\text { launch }\end{array}$ & $\begin{array}{l}\text { Enhance profit likelihood } \\
\text { Improve managerial } \\
\text { efficiency } \\
\text { System engineering } \\
\text { implementation }\end{array}$ \\
\hline 4 & $\begin{array}{l}\text { Increm } \\
\text { ental }\end{array}$ & $\begin{array}{l}\text { Cro } \\
\text { wd } \\
\text { S. }\end{array}$ & $\begin{array}{l}\text { Perf } \\
\text { o. }\end{array}$ & $\begin{array}{l}\text { Non-equity Share } \\
\text { Imitation } \\
\text { Incomplete contracts }\end{array}$ & $\begin{array}{l}\text { Non Disclosure } \\
\text { Agreement } \\
\text { Licensing } \\
\text { Patents } \\
\end{array}$ \\
\hline 5 & $\begin{array}{l}\text { Increm } \\
\text { ental }\end{array}$ & $\begin{array}{l}\text { Joint } \\
\text { R\& } \\
\text { D }\end{array}$ & $\begin{array}{l}\text { Perf } \\
\text { o. }\end{array}$ & $\begin{array}{l}\text { Not sufficient use in } \\
\text { alliance (by partners/by the } \\
\text { firm itself) } \\
\text { Low utility (low } \\
\text { benefit/cost) }\end{array}$ & $\begin{array}{l}\text { Enhance utility by license } \\
\text { used in network } \\
\text { Physical resources } \\
\text { flexibility }\end{array}$ \\
\hline 6 & $\begin{array}{l}\text { Increm } \\
\text { ental }\end{array}$ & $\begin{array}{l}\mathrm{R} \& \\
\mathrm{D} \\
\text { Cont } \\
\end{array}$ & $\begin{array}{l}\text { Perf } \\
\text { o. }\end{array}$ & $\begin{array}{l}\text { Financial shortfall } \\
\text { Non profit } \\
\text { No appropriate Time-to- } \\
\text { market } \\
\text { No appropriate Time-to- } \\
\text { launch }\end{array}$ & $\begin{array}{l}\text { Improve managerial } \\
\text { efficiency } \\
\text { Enhance profit } \\
\text { SWOT analyse }\end{array}$ \\
\hline 7 & $\begin{array}{l}\text { Increm } \\
\text { ental }\end{array}$ & $\begin{array}{l}\text { Cro } \\
\text { wd } \\
\text { S. }\end{array}$ & $\begin{array}{l}\text { Rela } \\
\text { t. }\end{array}$ & $\begin{array}{l}\text { Low authority } \\
\text { Imitation } \\
\text { No trust }\end{array}$ & $\begin{array}{l}\text { Non Disclosure } \\
\text { Agreement } \\
\text { Memorandum of } \\
\text { Understanding } \\
\end{array}$ \\
\hline
\end{tabular}

\begin{tabular}{|c|c|c|c|c|c|}
\hline 8 & $\begin{array}{l}\text { Increm } \\
\text { ental }\end{array}$ & $\begin{array}{l}\text { Joint } \\
\text { R\& } \\
\text { D }\end{array}$ & $\begin{array}{l}\text { Rela } \\
\text { t. }\end{array}$ & $\begin{array}{l}\text { Accidental knowledge } \\
\text { leakage } \\
\text { Intentional knowledge } \\
\text { leakage } \\
\text { Core competency lose }\end{array}$ & $\begin{array}{l}\text { Placement of Managers } \\
\text { in alliance key positions } \\
\text { Long term Contracts } \\
\text { Partners integration }\end{array}$ \\
\hline 9 & $\begin{array}{l}\text { Increm } \\
\text { ental }\end{array}$ & $\begin{array}{l}\text { R\& } \\
\text { D } \\
\text { Cont }\end{array}$ & $\begin{array}{l}\text { Rela } \\
\text { t. }\end{array}$ & $\begin{array}{l}\text { Non-equity Share } \\
\text { Lose of control }\end{array}$ & $\begin{array}{l}\text { Financial Control } \\
\text { Long term Contracts }\end{array}$ \\
\hline $\begin{array}{l}1 \\
0\end{array}$ & $\begin{array}{l}\text { Radica } \\
1\end{array}$ & $\begin{array}{l}\text { Cro } \\
\text { wd } \\
\text { S. }\end{array}$ & $\begin{array}{l}\text { Rela } \\
\text { t. }\end{array}$ & $\begin{array}{l}\text { No efficiency } \\
\text { Unstable collaboration }\end{array}$ & $\begin{array}{l}\text { Short term, recurrent } \\
\text { contracts (conditioned by } \\
\text { previous performances) }\end{array}$ \\
\hline $\begin{array}{l}1 \\
1\end{array}$ & $\begin{array}{l}\text { Radica } \\
1\end{array}$ & $\begin{array}{l}\text { Joint } \\
\text { R\& } \\
\text { D }\end{array}$ & $\begin{array}{l}\text { Rela } \\
\text { t. }\end{array}$ & $\begin{array}{l}\text { Accidental knowledge } \\
\text { leakage } \\
\text { Intentional knowledge } \\
\text { leakage } \\
\text { Core competency lose }\end{array}$ & $\begin{array}{l}\text { Improve managerial } \\
\text { efficiency }\end{array}$ \\
\hline $\begin{array}{l}1 \\
2\end{array}$ & $\begin{array}{l}\text { Radica } \\
1\end{array}$ & $\begin{array}{l}\mathrm{R} \& \\
\mathrm{D} \\
\text { Cont } \\
\end{array}$ & $\begin{array}{l}\text { Rela } \\
\text { t. }\end{array}$ & $\begin{array}{l}\text { Non-equity Share } \\
\text { Lose of control }\end{array}$ & $\begin{array}{l}\text { Improve managerial } \\
\text { efficiency } \\
\text { Short term, recurrent } \\
\text { contracts (conditioned by } \\
\text { previous performances) }\end{array}$ \\
\hline
\end{tabular}

\section{ILLUSTRATION}

To illustrate our proposal, we develop the case of the new drug development. NPD projects in pharmaceutical laboratory consist in developing new medicine for the treatment of human diseases. The attrition level is exceptionally high; less than one-in-ten projects launched in development is a technical success. The nine others are sacrificed in the no-go process [32]. These projects are innovative, costly but very risky. The development of a new product in the pharmaceutical industry has to go through a precise succession of phases, which take between 7 and 12 years depending on the level of innovation and the disease targeted. Paul et al. indicate that the cost of a new drug development is average $873 \mathrm{M} \$$.

Pharmaceutical companies establish alliances to develop new medicine. The type of alliance depends on the level of innovation, the availability of competences and the type of the company (big pharma, middle pharma, start up). When a laboratory starts a new development, decisions on strategic alliances have to be taken. In this context, strategic alliance is a relationship where two laboratories contribute. They bring different but complementary resources and capabilities to achieve a common objective. One of the most common bilateral alliances observed in the pharmaceutical sector is made by a small laboratory, or start up that own a patent and the first proof of effeicience. A collaboration with a big compagny will provide the budget to go deeply in the tests and development. The risks are shared and the project is contractualised [33]. Therefore, in this collaborative situation, the height following cells of the cube can be observed: $2,3,5$, $6,8,9,11,12$. One of the main identified risks is therefore the absorption of the startup by the big company.

\section{CONCLUSIONS AND PERSPECTIVES}

When designing a NPD Project, the decision maker goes through different and successive decision to make innovative product. In this paper we consider the innovation type, the collaboration and the risk management. The problematic addressed in this paper is to help the manager building a risk management plan to make the project robust to the risks. 
In this work we formalize the macro-process leading to the project risk management plan. We propose a reading frame of the project characteristics and a table allowing identifying possible risks and associated strategies.

This work gives a macroscopic vision of the influence of the innovation and alliance on the project risk level. This approach helps the decision maker establishing the project risk management plan.

One of the main biases of this approach is the fact that project considered are categorized in cells. In reality each criteria is a kind of continuum. Moreover, for one project, regarding the different macro-phases, the position can be in different cells and not only range in one cell for a project.

The main perspective is to take into account the effect of the alliance selection combined with the risk management on the project planning.

\section{REFERENCES}

[1] F. Wohlfeil, Terzidis O.: Critical Success Factors for the strategic management of radical technological innovation, IEEE International ICE Conference on Engineering, Technology and Innovation, Bergamo 2014, $1-9$.

[2] A. Rindfleisch, Moorman, C. The Acquisition and Utilization of Information in New Product Alliances: A Strength of-Ties Perspective. Journal of Marketing 65(2), 2001, 1-18

[3] P. Ritala, Olander, H., Michailova, S., Husted, K.: Knowledge sharing, knowledge leaking and relative innovation performance: An empirical study. Technovation, 35, 2015, 22-31.

[4] H. W. Chesbrough, Open Innovation: The New Imperative for Creating and Profiting from Technology. Boston, Harvard Business School Press, 2003.

[5] P. Nightingale, The product-process-organisation relationship in complex development projects. Research Policy, 29, 2000, 913-930.

[6] P. Badke-Schaub, Neumann, A., Lauche K, and Mohammed, S.: Mental models in design teams: a valid approach to performance in design collaboration? CoDesign, 3, 2007, 5-20.

[7] B. Townley, Beech, N., and McKinlay, A.: Managing in the creative industries: Managing the motley crew. Human Relations, 62(7), 939-962 (2009)

[8] G. Pahl, Beitz W., Feldhusen J., Grote K.H.: Engineering Design, A Systematic Approach, 3rd Edition, Springer (2007)

[9] J.S. Gero, Design prototypes: a knowledge representation schema for design. AI magazine, 11 (4), 26-36 (1990)

[10] N.F.O. Evbuomwan, Sivaloganathan, S. and Jebb, A.: A survey of design philosophies, models, methods and systems. Proceedings of the Institution of Mechanical Engineers, 210(42), 301-320 (1996)

[11] C. Freeman, Networks of Innovators: A Synthesis of Research Issues. Research Policy 20, no. 6 (1991)

[12] T. K. Das, Teng, B. S.: Resource and Risk Management in theStrategic Alliance Making Process. Journal of management, Vol. 24(1), 21-42 (1998)

[13] Z. Emden, Calantone, R. J., Droge, C.: Collaborating for new product development: selecting the partner with maximum potential to create value. Journal of product innovation management, 23(4), 330-341 (2006)
[14] M. E. Porter, Fuller, M.: Coalitions and global strategy'. In M. Porter (ed.), Competition in Global Industries. Harvard Business School Press, Boston, MA, 315-343 (1986)

[15] T. K. Das, Teng, B. S.: A risk perception model of alliance structuring. Journal of International Management, 7(1), 1-29 (2001)

[16] J.A. Schumpeter, Capitalism, Socialism and Democracy. Harper and Broth-ers, New-York (1950)

[17] D. R. Gnyawali, Srivastava, M. K.: Complementary effects of clusters and networks on firm innovation: A conceptual model. Journal of Engineering and Technology Management, 30(1), 1-20 (2013)

[18] M.Y. Yoshino, Rangan, U.S.: Strategic Alliances: An Entrepreneurial Approach to Globalization. Harvard Business School Press, Boston, MA (1995)

[19] P.Dussauge, Garrette, B.: Determinants of success in international strategic alliances: evidence from the global aerospace industry. J. Int Bus. Stud. 26, 505-530 (1995)

[20] J. G. March, Exploration and exploitation in organisational learning, Organisation, Science, 2 (1), 71-87 (1991)

[21] J. Hagedoorn, Inter-firm R\&D Partnerships: An Overview of Major Trends and Patterns since 1960. Research Policy 31(4), 477-92 (2002)

[22] B. Nooteboom, Van Haverbeke, W., Duijsters, G., Gilsing, V., and Van den Oord, A.: Optimal cognitive distance and absorptive capacity. Research Policy, 36/7, 1016-1034 (2007)

[23] J.B. Barney, Firm resources and sustained competitive advantage. Journal of Management 17 (1), 99-120 (1991)

[24] O. Gassmann : Opening up the innovation process: towards an agenda, R\&D Management, 36 (3), 223-228 (2006)

[25] R. N. Osborn, Baughn, C. C.: Forms of inter-organizational governance for multinational alliances. Academy of Management Journal, 33: 503519 (1990)

[26] P. S. Ring, Van de Ven, A. H.: Developmental processes of cooperative interorganizational relationships. Academy of Management Review 19, 90-118 (1994)

[27] D. Littler, Leverick, F. and Bruce, M.: Factors Affecting the Process of Collaborative Product Development: A Study of UK Manufacturers of Information and Communications Technology Products. Journal of Product Innovation Management 12(1):16-33 (1995)

[28] L.G. Tornatzky, Fleischer, M.: The processes of technological innovation, Lexington Books, Lexington, Mass, (1990)

[29] T. Nguyen, Marmier, F., Gourc, D.: A decision-making tool to maximize chances of meeting project commitments, International Journal of Production Economics, 142(2) p. 214-224 (2013)

[30] F. Marmier, Gourc, D., Laarz, F.: A risk oriented model to assess strategic decisions in new product development projects, Decision Support Systems, 56, p. 74-82 (2013)

[31] F. Marmier, Filipas Deniaud, I., Gourc, D.: Strategic decision-making in NPD projects according to risk: application to satellites design projects, Computers in Industry, 65(8), 1107-1114 (2014)

[32] S. M. Paul, Mytelka, D. S., Dunwiddie, C. T., Persinger, C. C., Munos, B. H., Lindborg, S. R., Schacht, A. L.: How to improve R\&D productivity : the pharmaceutical industry's grand challenge, Nature Reviews Drug Discovery 9 (3) 203-214 (2010)

[33] Exporting Pharmaceuticals: A Guide for Small and Medium-Sized Exporters, ITC International Trade Centre UNCTAD/WTO, (2005) 